\title{
Goederevervoermarksegmente wat potensieel winsgewend deur spoorvervoer bedien kan word
}

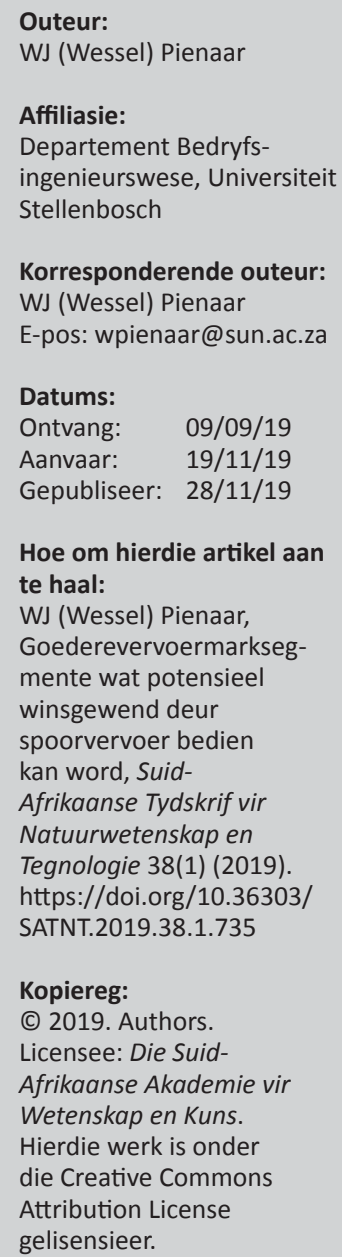

\begin{abstract}
Hierdie oorsigartikel bied 'n uiteensetting van goederevervoermarksegmente wat potensieel winsgewend deur spoorvervoer bedien kan word. Die werkwyse word beskryf waarvolgens die marksegmentering wat vir die studie tersaaklik is, uitgevoer is. Ten aanvang word ondersoek watter vraagvereistes goedereversenders uit 'n doeltreffendheidsoogpunt aan 'n vervoerdiens stel. Dan word die ekonomiese kenmerke van die onderskeie goederevervoermodusse ondersoek om te bepaal watter kenmerke uit 'n kostedoelmatigheidsoogpunt by die aanbod van 'n vervoerdiens bepalend is. Uit hierdie vraag-en-aanbod-oorwegings is 'n sintese van die vyf modale segmente van die goederevervoermark opgestel, naamlik lug-, pad-, spoor-, pypleiding- en skeepsvervoer. Binne die modale spoorgoederevervoermark in die besonder word ses potensieel winsgewende subsegmente geïdentifiseer. Hierdie subsegmente word bepreek aan die hand van die volgende vier kenmerke wat elkeen tipeer: (1) soort treine aangewend, (2) soort trokke benut, (3) soort eindpunte gebruik en (4) soort goedere vervoer. Die geïdentifiseerde subsegmente van die spoorgoederevervoermark is soos volg: (1) losmaatgoederevervoer, (2) grootmaatvervoer van (a) mynbouprodukte, (b) vloeistowwe en (c) graan; (3) op-enafrydienste en (4) standaard- intermodale houervervoer.
\end{abstract}

Freight transport market segments that can potentially be served profitably by rail transport: This review article gives details of freight transport market segments that can potentially be served profitably by rail transport. The methodology followed to segment the freight transport market for the purpose of the investigation is explained. First, shippers' demand requirements for a transport service from an effectiveness viewpoint are identified. Then the economic features of the different freight transport modes that are pertinent in a transport service from an efficiency point of view are identified. Based on these demand and supply considerations, a synthesis is made of the five modal segments of the freight transport market, namely air, road, rail, pipeline and ship transport. In the modal rail freight transport market specifically, six potentially profitable subsegments are identified. These subsegments are discussed in terms of the following four features that typify each one: (1) train types operated, (2) wagon types used, (3) terminal facility types employed and (4) type of goods conveyed. The following subsegments are identified: (1) break-bulk freight transport, (2) bulk transport of (a) mining products, (b) liquids and (c) grain; (3) rollon/roll-off freight transport and (4) standard intermodal container transport.

\section{Inleiding}

Hierdie oorsigartikel is die eerste van drie. Dié aflewering handel oor goederevervoermarksegmente wat belofte toon om winsgewend deur spoorvervoer bedien te word indien die aanbod daarvan doelmatig en doeltreffend geskied. Die tweede aflewering handel oor die plasing van spoorlyne en spoorvervoereindpunte ten einde 'n goederespoorstelsel so toeganklik te maak dat dit suksesvol bydra om nut (of waarde) te help skep. Die laaste aflewering handel oor die funksionele rol van spooreindpuntgeriewe om die suksesvolle vervoer van goedere per spoor te onderskraag.

Die drie aflewerings bou voort op twee artikels wat in 2007 en 2017 gepubliseer is. Die eerste artikel het gehandel oor voorstelle vir 'n reguleringsraamwerk vir pad- en spoorvragvervoer in Suid-Afrika (Pienaar 2007:265-278), en die tweede oor bedryfs- en tegnologiese vereistes vir die winsgewende lewering van spoorgoederevervoer (Pienaar 2017:79-89).

Die navorsingsvraag wat hierdie artikel ten doel het om te beantwoord, is of daar 'n duidelike plek vir spoorvervoer in 'n ekonomies gedereguleerde goederevervoermark is en indien wel, 
watter goederevervoermarksegmente potensieel winsgewend deur spoorvervoer bedien kan word. Hierdie navorsingsvraag of studiebehoefte word in meer besonderhede in afdeling 2 bespreek. Afdeling 3 word aan die ondersoekmetode gewy wat gevolg is om die navorsingsvraag te beantwoord. In afdeling 4 word die marksegmente wat winsgewend deur spoorgoederevervoer bedien kan word, geïdentifiseer. Die besondere uitgangspunt wat die identifikasieproses onderlê het, word in onderafdeling 4.1 vermeld. Die vraagvereistes wat voornemende goedereversenders uit 'n doeltreffendheidsoogpunt aan 'n vervoerdiens stel, word onderafdeling 4.2 uiteengesit. Die ekonomiese aspekte van die onderskeie goederevervoermodusse om te bepaal watter van dié aspekte uit 'n kostedoelmatigheidsoogpunt deurslaggewend is by die aanbod van 'n vervoerdiens deur elke modus, word in onderafdeling 4.3 ondersoek. 'n Sintese van die modale segmente van die goederevervoermark word in onderafdeling 4.4 aangebied. Die navorsingsvraag wat die artikel stel, word in afdeling 5 beantwoord. Die gevolgtrekkings wat uit die studie vloei, word in afdeling 6 geformuleer.

\section{Studiebehoefte}

Transnet het die Universiteit Stellenbosch in 1993 versoek om die stand van die spoorgoederevervoerbedryf in nywerheidslande te ondersoek, die stand daarvan te sintetiseer en die waarskynlike toekomsrol van spoorgoederevervoer in 'n ekonomies gedereguleerde goederevervoermark in Suid-Afrika te visualiseer en verslag daaroor te doen. Die redes vir hierdie versoek van Transnet word deur Pienaar $(2017: 79,80)$ uiteengesit. Gedurende die vroeë 1970's het padvervoer in Suid-Afrika spoorvervoer begin vervang as die oorheersende vorm van vragvervoer oor lang afstande, met uitsondering van die vervoer van erts. In 1993 was padvragkarweiers al vir langer as twee dekades besig om hulle markaandeel te vergroot ten opsigte van niegrootmaatverkeer op langafstandroetes waarop spoorvervoer eintlik die goedkoopste modus is (Pienaar 2007:269).

Dit was duidelik dat die groter waarde wat padgoederekarweiers deur beter diensgehalte in vergelyking met dié van spoorvervoer gebied het, toenemend besig was om hulle groter koste in vergelyking met dié van spoorvervoer te oortref. Die standpunt het posgevat dat die gevolge van ondoeltreffende ekonomiese regulering en die beskerming van spoorvervoerkarweiers deur state meermale skadeliker as die gevolge van markmislukkings is.

Transnet het die onomkeerbaarheid van die opbloei van padgoederevervoer as ' $n$ gegewe aanvaar en besef dat sy spoorgoederevervoerfiliaal (die destydse Spoornet, en tans Transnet Freight Rail) in 'n ekonomies vrye vervoermark nie meer sou kon (of hoef te) probeer om "alles vir almal" te wees nie. Daarom wou Transnet groter toekomssekerheid hê oor die goederemarksegmente waarbinne hy in 'n ekonomies gedereguleerde markbedeling potensieel winsgewend sou kon meeding.

Die oogmerke van hierdie artikel is (1) om 'n oorsig te gee van goederevervoermarksegmente wat belofte toon om winsgewend deur spoorvervoer bedien te word, en (2) om diewerkwysetebeskryf waarvolgens diemarksegmentering wat vir die ondersoek nodig was, uitgevoer is. In hierdie artikel beteken "marksegmentering" die proses waardeur die gedifferensieerde goederevervoermark in groepe verdeel word wat elkeen soortgelyke vraag-en-aanbodeienskappe het.

\section{Ondersoekmetode}

Die ondersoek is uitgevoer deur stede en vervoereindpunte in nywerheidslande te besoek waarin spoorgoederevervoerbedrywighede op groot skaal plaasvind, en deur onderhoude en korrespondensie met verteenwoordigers van spoorgoederevervoeroperateurs te voer. Die ondersoeke ter plaatse is aangevul deur 'n literatuurstudie oor die onderwerp van die ondersoek. Spoorvervoerbedrywighede in 36 plekke op ses kontinente is besoek. Die spesifieke plekke wat tot en met 2015 besoek is, word in Pienaar (2017:80) verstrek. Die volledige lys plekke wat tot 2019 vir navorsingsdoeleindes besoek is, is soos volg: Atlanta, Baltimore, Boston, College Station (in Texas), Chicago, Montreal, New York, Oakland (in die San Franciscobaai-gebied), Seattle en Vancouver in NoordAmerika; Berlyn, Bremen, Frankfurt, Hamburg, Leipzig, Mannheim, München, Rome en Rotterdam in Europa; Auckland, Brisbane, Sydney en Wellington in Australasië; Casablanca, Durban, Johannesburg, Kaapstad, Kaïro, Marrakesj, Richardsbaai en Saldanhabaai in Afrika; en Beijing, Busan, Hongkong, Shanghai en Singapoer in Asië. (Let op dat die spesifieke Afrikabestemmings buite SuidAfrika eerder in "nywerheidsenklawes" as in nywerheidslande geleë is.)

\section{Marksegmente wat winsgewend deur spoorgoederevervoer bedien kan word Uitgangspunt}

Om te bepaal watter marksegmente potensieel winsgewend deur spoorgoederevervoer bedien kan word, is ten aanvang ondersoek watter vraagvereistes voornemende goedereversenders uit 'n doeltreffendheidsoogpunt aan 'n vervoerdiens stel. In hierdie studie word doeltreffendheid beskou as die mate van sukses met die voorsiening van 'n goederevervoerdiens soos wat dit deur gebruikers daarvan ervaar word, dit wil sê hoe goed die vervoerdienste aan die gebruikers se verwagtinge voldoen. As ' $n$ prestasiemaatstaf is doeltreffendheid dus 'n meting van hoe goed die doel getref is. Hiervoor is die bedryfsvoordele en -nadele van die onderskeie goederevervoermodusse ondersoek. 
Daarna is die ekonomiese aspekte van die onderskeie goederevervoermodusse ondersoek om te bepaal watter van dié aspekte uit 'n kostedoelmatigheidsoogpunt deurslaggewend is by die aanbod van die vervoerdiens deur elke modus. Die doelmatigheid waarmee insette georganiseer en aangewend word om vasgestelde doelwitte te bereik, het 'n regstreekse uitwerking op die mededingendheid van 'n onderneming. Hoe laer die eenheidskoste van 'n hoeveelheid vervoeruitset van gegewe gehalte is in verhouding tot die waarde of prys daarvan, hoe groter is die doelmatigheid van die vervoerproses. As ' $n$ prestasiemaatstaf is doelmatigheid dus 'n meting van hoe matig daar te werk gegaan word om die doel te bereik.

\section{Doeltreffendheidsoorwegings ${ }^{1}$}

Doeltreffende goederevervoer is 'n voorvereiste om te help verseker dat kliënte die vereiste goedere op die aangewese tyd en bestemde plek in die verlangde toestand en hoeveelheid ontvang. Die vernaamste vervoerdiensmaatstawwe is (1) geskiktheid, (2) toeganklikheid, (3) goederesekuriteit, (4) deurvoertyd, (5) buigsaamheid en (6) betroubaarheid (Andersen 1995:220-225; Anderson en Basson 1997:62; BER 2003:299,300; COTO 2017:ii; Coyle et al. 2017:439-443; ECMT 2004:12; Liberatore en Miller 1995:88; Pienaar 2007:270; Pretorius 1997:81, 8-2; Stock en Lambert 2001:357). Dié ses maatstawwe word in die volgende paragrawe bespreek.

Geskiktheid behels dat die vervoerdiensverskaffer oor die gepaste voertuie, hanteringstoerusting en geriewe moet beskik en dit kan aanwend soos wat die vervoer van 'n bepaalde goederesoort vereis. Voertuie wat temperatuur en ventilasie kan beheer, voertuie met spesiale geriewe en voertuie wat buitengewoon gevormde, groot of swaar items kan hanteer en dra, illustreer geskiktheid.

Toeganklikheid kan enersyds as 'n eienskap van 'n karweier en andersyds as ' $n$ kenmerk van ' $n$ besondere plek beskou word. (1) Uit die oogpunt van 'n karweier is dit die vermoë om 'n diens tussen spesifieke fasiliteite te lewer en om fisies toegang tot sulke fasiliteite te verkry. (2) As 'n kenmerk van 'n plek behels toeganklikheid die gemak waarmee dit bereik kan word - dit weerspieël die aantreklikheid van 'n plek as ' $n$ oorsprong (hoe maklik dit is om van daar af elders te kom - in hierdie geval met spoorvervoer) of as 'n bestemming (hoe maklik dit is om daar te kom van elders af).

Goederesekuriteit behels dat goedere in dieselfde fisiese toestand en hoeveelheid aankom en afgelewer word as waarin dit vir karwei beskikbaar gestel is. Onsekere vervoer kan lei tot (1) inkomsteverlies weens produktiwiteitsafname omdat goedere nie vir produktiewe aanwending beskikbaar is nie, of (2) regstreekse winsverlies omdat goedere teen 'n laer as die verwagte prys verkoop moet word, of onverkoopbaar is.

Deurvoertyd is die totale tyd wat verloop vandat die versender die goedere vir karwei beskikbaar stel, totdat dit by die ontvanger afgelewer word. Dit sluit wag-, oplaai-, aflaai-, hanterings- en reistyd in.

Buigsaamheid (of veerkragtigheid) is die vermoë om doeltreffend wisselinge te hanteer in (1) loonvragmassa, (2) loonvragvolumes, (3) oplaai- en aflaaitye en (4) oplaai- en aflaailiggings sonder om wesenlik aan doelmatigheid in te boet.

Betroubaarheid is die bestendige handhawing van deurvoertyd. Dit is die bewese vermoë van 'n karweier om telkens afgespreekte oplaai- en aflaaitye na te kom.

Betroubaarheid is dikwels die belangrikste vervoerdiensmaatstaf. Die uitwerking van betroubare deurvoertyd, eerder as die duur van deurvoertyd, op voorraadvlakke, uitvoorraadkoste en kliëntediens is hier van belang. Die vernaamste rede waarom kliënte betroubaarheid merendeels belangriker as deurvoertyd ag, is kennelik dat bestendige handhawing van stiptelikheid onontbeerlik vir logistieke en ander bedryfsbeplanning is. 'n Onderneming sal byvoorbeeld eerder daarop ingestel wees om besendings te ontvang wat telkens op die bestemde tyd aankom, as een maal vroeg, een maal laat, een maal op die bepaalde tyd, ensovoorts. Al bied 'n karweier dus korter deurvoertye aan, maar die lewering gaan gepaard met wisselvallige afleweringstye, sal 'n versender geneig wees om ' $n$ karweier te kies wat ondanks langer deurvoertye konsekwent stiptelik is. ' $n$ Konsekwente, stiptelike diens lei tot heelwat voordele, waaronder (1) groter klandisiewaarde, (2) gunstiger bemarkingsgeleenthede, (3) die vermoë om fyner te beplan, (4) minder uitvoorraadsituasies, en (5) voorraadhoukostebesparings tel, wat' $n$ bron van mededingingsvoordeel is.

'n Veralgemeende diensvergelyking van die verskillende goederevervoermodusse vanuit 'n bedryfsoogpunt, soos geblyk het uit die ondersoek, word in Tabel 1 weergegee.

\section{Doelmatigheidsoorwegings ${ }^{2}$}

Doelmatigheid kan ekonomies en tegnies beskou word: (1) Ekonomies gesproke het doelmatigheid betrekking op die optimale (beste) gebruik van hulpbronne sodat die grootste opbrengs of voordeel van enige gegewe stel hulpbronne behaal word, en (2) tegnies gesproke het doelmatigheid betrekking op die kombinasie van die beste en modernste bedryfstegnieke; 'n toepaslik geskoolde werksmag; gesonde bestuur; en die organisering van die onderneming 
TABEL 1: Benaderde diensvergelyking van goederevervoermodusse

\begin{tabular}{l|c|c|c|c|c}
\hline Dienseienskappe & \multicolumn{4}{|c}{ Vergelykende prestasie in algemene terme } \\
\hline Geskiktheid & Hoogste & Spoor & Pad & Lug & Laagste \\
Toeganklikheid & Water & Spoor & Lug & Pater & Wyp \\
Goederesekuriteit & Pad & Lug & Pad & Water & Spoor \\
Deurvoertyd & Lug & Pad & Spoor & Water & Pyp \\
Buigsaamheid & Pad & Spoor & Lug & Spoor & Water \\
Betroubaarheid & Pyp & Lug & Pad & & Pyp \\
\hline
\end{tabular}

Bron: Eie navorsing

sodat dit met 'n grootte wat maksimale skaalvoordele bied, bedryf word.

Die normale siening van skaalvoordele is dat hoe groter die produksievermoë van 'n onderneming is (dit wil sê die grootte van 'n onderneming, vloot of aanleg - die drie begrippe word hier sinoniem gebruik), hoe laer is die langtermyn- gemiddelde produksiekoste per eenheid. In goederevervoer word dit gewoonlik as koste per netto tonkilometer uitgedruk ("netto" beteken hier dat net die loonvrag se massa in berekening gebring word en nie dié van die rollende materiaal ook nie).

Skaalvoordele in vervoer hang af van die verkryging van een of meer subgroepe daarvan: (1) digtheidsvoordele, (2) verskeidenheidsvoordele en (3) ritafstandvoordele. Dié drie subgroepe word in die volgende paragrawe bespreek.

Digtheidsvoordele word behaal wanneer die koste per netto ton-kilometer om 'n sekere aantal goederebesendings vanaf hulle ritoorspronge tot by hulle gewenste bestemmings te vervoer, afneem as gevolg van verhoogde werkverrigting van die beskikbare voertuigvloot in 'n gegewe roetenetwerk of markgebied.

'n Hoeveelheid goedere kan dikwels teen 'n laer eenheidskoste vervoer word as dit saam in een besending vervoer word, eerder as in verskillende deelbesendings. Hierdie soort skaalvoordele spruit daaruit dat die grootste moontlike deel van 'n mark met dieselfde tegnologie bedien kan word. Dieselfde volume deurset vind plaas, maar die beweging is in een proses gekonsentreer, wat 'n intensiewer gebruik van die betrokke kapitaaltoerusting bewerkstellig.

Digtheidsvoordele word aangehelp deur (1) gespesialiseerde en duursame hoëvermoëtegnologie te gebruik om groot volumes van 'n spesifieke of homogene soort vrag in ritte oor die langs moontlike tydperk veilig te dra en te hanteer; (2) individuele rittye te beperk en die aantal ritte te maksimeer; en (3) verkeerskonsolidering (dit behels die konsolidering van vragte, ritte, roetes en laaipunte) te benut om sodoende voertuie se gelyktydige en volgtydelike benutting te maksimeer. Gelyktydige benutting het betrekking op die mate waarin die dravermoë (soos in (1) vermeld) van voertuie benut word, terwyl volgtydelike benutting (soos in (2) vermeld) betrekking het op die aantal inkomstekilometers of inkomsteritte per tydperk.
Die inherente gevaar van die gebruik van gespesialiseerde toerusting is die leë terugrit en ledige staantye, wat die handhawing van goeie volgtydelike benutting en daarom ook die bereiking van 'n hoë vlak van digtheidsvoordele kortwiek. Uit die ondersoek het dit geblyk dat goeie digtheidsvoordele in spoorvervoer behaal kan word deur die bedryf van (1) die langs moontlike treine wat tegnies haalbaar is, met doelgeboude trokke en gepaste lokomotieftrekkrag wat loonvragdravermoë maksimeer, met (2) voldoende lynkapasiteit om die rittyd van treine tussen eindpunte op veilige wyse te verkort, en (3) ingerigte eindpuntgeriewe met gepaste hanteringstoerusting om vinnige op- en aflaai van vrag toe te laat en daardeur die algehele rittye van treine verkort. (Wanneer leë terugritte nie vermy kan word nie en inkomste daarom slegs op heenritte verdien word, is die aangewese weg om ter wille van inkomste-maksimering te volg die minimering van retoerrittye en sodoende die aantal ritte per tydperk te maksimeer.)

Verskeidenheidsvoordele word behaal wanneer die produksiekoste van twee of meer produkte saam - in óf 'n gesamentlike óf 'n gemeenskaplike proses - minder is as die afsonderlike produksiekoste daarvan.

Gesamentlike produkte (ook genoem neweprodukte) is die onafwendbare en onskeibare gevolg van 'n enkele produksieproses. 'n Uitwaartse reis lei byvoorbeeld outomaties tot ' $n$ inwaartse reis - want al word vrag net in een rigting vervoer, moet die voertuig steeds na sy tuisdepot terugkeer. Dit impliseer dat as 'n volle voertuigvrag van tuisdepot A na punt B vervoer moet word, die karweiding van 'n vrag terug van punt $B$ na tuisdepot $A$ die gemiddelde koste van die twee vragte laer sal maak as die vragkoste van karweiding slegs van A na B, aangesien die voertuig in elk geval na sy tuisdepot moet terugkeer. Indien beskikbare vrag vir die terugreis nie gewerf kan word nie, is dit 'n verlore inkomstegeleentheid, en dit impliseer dus dat gesamentlike koste nie winsgewend gehanteer is nie aangesien die koste van die volle retoerrit deur die verkeer op die heenreis van A na B gedek moet word.

Gemeenskaplike produksie (ook genoem gedeelde produksie) vind plaas wanneer verskillende produkte doelbewus saam in 'n gemeenskaplike proses geproduseer word. In hierdie geval kan dieselfde tegnologie gebruik word danksy die ooreenkomste tussen die produksieprosesse. Die koste wat hieruit spruit, is gemeenskaplik en word dus 
tussen die gemeenskaplik geproduseerde produkte gedeel. In spoorvervoer kom dit byvoorbeeld voor wanneer dieselfde trein vir die vervoer van passasiers en goedere gebruik kan word. Insgelyks, wanneer vlootvermoë die vraag oorskry van kontraktuele ooreenkomste wat seisoenaal wissel, kan die vloot se ongebruikte vermoë in die valleiperiodes tussen die spitstydperke teen verlaagde tariewe met lokomark- (spot market) verskepings opgeneem word.

Ritafstandvoordele word behaal wanneer dieeenheidskoste per ton-kilometer afneem namate die roete-afstand toeneem. Hierdie voordele ontstaan wanneer daar ritspesifieke koste voorkom wat nie deur die afstand van die reis geraak word nie. 'n Voorbeeld is eindpuntkoste (byvoorbeeld koste verbonde aan ritdokumentasie en goederehantering - veral wat op- en aflaaikoste en die tydsduur daarvan betref). Aangesien hierdie koste ongeag die afstand aangegaan moet word, lei die verdubbeling van die afstand van die reis nie tot verdubbeling van koste nie. Om ritafstandvoordele te maksimeer, moet die aflê van lang ritte gepaardgaan met die maksimering van die aantal inkomstegewende ritte per tydperk.

Uit die ondersoek het dit geblyk dat daar sewe ekonomiese aangeleenthede is wat ' $n$ beduidende rol by die aanbod van 'n goederevervoerdiens speel. Dié sewe aangeleenthede is soos volg: (1) kostevlak, (2) kostestruktuur, (3) vlootgroottevoordele, (4) voertuiggroottevoordele, (5) ritafstandvoordele, (6) oorheersende binnemodale mededingingstipe, en (7) oorheersende tussenmodale mededinging (Pienaar 2012:40-42). Hierdie ekonomiese aspekte van die onderskeie goederevervoermodusse word vervolgens bespreek en in Tabel 2 aangedui (Pienaar 2012:46).

Kostevlak: Pypleidingvervoer is, naas skeepsvervoer, die goedkoopste vervoermodus vir die soort kommoditeite wat per pypleiding vervoer kan word. Spoor- of padvervoer is die goedkoopste grondvervoermodusse vir al die goederesoorte wat nie per pypleiding vervoer kan word nie. Aangesien spoorvervoer aansienlike ritafstandvoordele behaal, word dit goedkoper as padvervoer vir alle soorte goedere namate ritafstande langer as sowat $500 \mathrm{~km}$ word (Africon 2008:20). (Hierdie stelling is slegs waar vir deurritte tussen oorsprong en bestemming - namate daar onderweg-oordrag van loonvrag tussen voertuie/treine plaasvind, vermeerder die ritkoste wat dus ritafstandvoordele benadeel.) Vir ritte korter as sowat $150 \mathrm{~km}$ is padvervoer egter bykans altyd goedkoper as spoorvervoer. Vir alle soorte goedere wat moontlik deur óf pad- óf spoorvervoer tussen dieselfde oorsprong en bestemming vervoer kan word, is die afstand waaroor die koste gelyk is, iewers tussen sowat 150 en $500 \mathrm{~km}$ (Pienaar 2007:269: Pienaar 2012:41).

Kostestruktuur: Kostestruktuur het betrekking op die verhouding van vaste koste tot totale koste. Omdat spoorvervoer groot aanvanklike investering in spoorinfra- struktuur en duursame rollende materiaal soos lokomotiewe en goederetrokke verg, is die verhouding van vaste tot totale koste baie hoog - die tweede hoogste van alle vervoermodusse ná pypleidingvervoer (Department of Logistics, Stellenbosch University 1998:30). Sowat 75\% van spoorvervoerkoste is oor die kort termyn vaste koste (Havenga en Pienaar 2012:2).

Voordele van vlootgrootte: Hierdie voordele in spoorvervoer word verkry deur lang treine te bedryf en die dravermoë daarvan goed te benut. In hierdie konteks geniet spoorvervoer die hoogste vlak van vlootgroottevoordeel van alle vervoermodusse.

Volgens Van de Venter (1989:afd. 5) is die voordele wat spruit uit die bedryf van die langste treine wat tegnies moontlik is en die gebruik van meervoudig-gekoppelde lokomotiewe, soos volg: (1) meervoudig-gekoppelde lokomotiewe benodig slegs een lokomotiefbemanning; (2) die bedryf van lang treine is eenvoudiger en veiliger as dié van verskeie kort treine wat altesaam dieselfde hoeveelheid loonvrag as'n enkele lang trein dra; en (3) spoorlynbenutting verbeter omdat die vereiste minimum volgtye en volgafstande tussen kort en lang treine in verhouding minder verskil as die verskil in treinlengte.

Voertuiggroottevoordele: Die maksimum toelaatbare hoogte en breedte van trokke word deur die heersende laaiprofiel van ' $n$ spoorstelsel bepaal, terwyl die lengte van trokke beperk word deur hul strukturele robuustheid, naamlik hulle vermoë om die druk van vragmassa op trokseksies wat nie regstreeks deur asse en wiele ondersteun word nie, te weerstaan, en deur die maksimum aslas wat die spoorinfrastruktuur kan hanteer. Die laaiprofiel definieer die maksimum hoogte en breedte van spoorvoertuie en hul vrag om veilig oor brûe, deur tonnels en verby of onderdeur ander voorwerpe te beweeg (University of Birmingham and Network Rail 2011:30). Die breedte van spoortrokke word hoofsaaklik beperk deur die wydte van die spoorlyn. Weens hierdie beperkings op voertuigafmetings, is die verkryging van voertuiggroottevoordele, tesame met dié van padvervoer, relatief gesproke die laagste van die vyf vervoermodusse (Bonsor 1984:96).

Ritafstandvoordele: Omdat die kostestruktuur van spoorvervoer 'n komponent hoë eindpuntkoste bevat, behaal dit aansienlike afstandsvoordele namate ritlengtes toeneem die hoogste van alle vervoermodusse.

Binnemodale mededinging: Die groot aanvangskoste en die hoë verhouding van vaste tot totale koste in spoorgoederevervoer bring mee dat dekking van totale koste deur inkomste op 'n hoë uitsetvlak plaasvind. Daarom moet 'n groot volume goederedienste verkoop word voordat ' $n$ wins behaal kan word. Dit kan impliseer dat ' $n$ wins net behaal kan word as daar 'n enkele spoorgoederekarweier in die mark is, dit wil sê as 'n natuurlike monopolie bestaan (Cowie 2010:289). Ekonomiese ken- 
merke soos hoë toegangsversperrings, skaalvoordele en hoë gelykbreekpunte het histories beteken dat spoorgoederevervoer 'n hoogs gekonsentreerde binnemodale mark was. Wat die aantal markdeelnemers betref, is die voorsiening van spoorgoederevervoer ná pypleidingvervoer die tweede mees gekonsentreerde van alle vervoermodusse.

Sedert die 1990's is die eienaarskap van spoorinfrastruktuur en treinbedrywighede in Europa en Australië op organisasievlak geskei. Hierdie reëling beteken enige voornemende spoorkarweier kan, op sekere voorwaardes, ope toegang tot bestaande spoorinfrastruktuur kry. Die voorstanders van hierdie nuwe spoorvervoerbedeling voer aan dat dit die toegangsversperrings verminder en monopolieë beperk, waardeur die spoorvervoermark meer mededingend gemaak word (ECMT 2004:16). Daar word gesê dat die potensiële of moontlike bedreiging van maklike marktoegang die bestaande operateur aanspoor om doelmatiger en doeltreffender te werk. Ondanks hierdie hervormings het min nuwe karweiers die spoorvragmark betree (Amos 2007:6; Pittman 2005:181). In lande waar die infrastruktuureienaarskap en treinbedrywighede geskei is, het karweiers die mark betree hoofsaaklik om aan 'n baie besondere behoefte van ' $n$ goedereversender of van ' $n$ klein nismark te voldoen. Tot dusver het ervaring getoon dat mededinging tussen spoorkarweiers in die nuwe bedeling ruimte laat vir die vorming van duopolieë, en nie groter oligopolieë met drie of meer gevestigde mededingers nie (Di Pietrantonio en Pelkmans 2004:27). ('n Duopolie is 'n mark waarin daar slegs twee aanbieders voorkom en 'n oligopolie is 'n mark waarin daar só min verkopers voorkom dat hulle mekaar se optrede in ag moet neem.)

Oorheersende tussenmodale mededinging: Spoorvervoer ding met padvervoer mee om losmaat- en behouerde goedere, veral oor ritafstande langer as $500 \mathrm{~km}$ waar spoorvervoer toenemend goedkoper as padvervoer raak. Omdat die eenheidskoste afneem wanneer die uitsetvermoë toeneem, behaal spoorvervoer aansienlike skaalvoordele (hoofsaaklik deur digtheids- en ritafstandvoordele) met hoë benutting - en selfs in hoër mate in die geval van lang treine en ' $n$ dubbelspoorstelsel (of ' $n$ enkel spoor met voldoende uitwykspore vir die verbygaan van aankomende treine en stadiger treine in dieselde rigting) met gespesialiseerde eindpuntgeriewe en hanteringstoerusting wat vinnige treinomdraaitye deur kort oplaai-, aflaai- en wagtye moontlik maak (Pienaar 2012:42).

Pypleidingvervoer is hoogs mededingend met ander grondvervoermodusse, veral as die volledige benutting van die pypleiding te alle tye moontlik is. Pypleidingtariewe per eenheid gekarwei is ongeveer een helfte van spoortariewe en een vyfde van padvervoertariewe (Africon 2008:35). Hoewel spoorvervoer duurder as pypleidingvervoer is, kan dit ' $n$ parallelle pypleidingdiens doeltreffend komplementeer wanneer dit voldoende beskikbare vermoë het en die pypleiding teen bykans volle vermoë bedryf word (Rabinow 2004:27).

Omdat pypleidingvervoer (1) die energiedoelmatigste vervoermodus is, (2) aansienlik goedkoper as pad- en spoorvervoer is, (3) heelwat veiliger as spoorvervoer en veralpadvervoeris,(4)pad-enspoorinfrastruktuurkapasiteit vir ander verkeer beskikbaar stel, (5) minder onverhaalde eksterne koste (soos lugbesoedeling, geraas en verkeersophopings) as ander vervoermodusse veroorsaak, en (6) hoë akkuraatheid en betroubaarheid van vooruitgeskatte afleweringstye handhaaf, verlaag dit die behoefte aan noodvoorraad by die eindpunt, terwyl gratis opbergplek gebied word so lank as wat die bestelling op pad is om afgelewer te word (Papacostas en Prevedouros 2001:240; Trench en Miesner 2006:8). Pypleidingvervoer behoort (waar 'n groot genoeg vervoerbehoefte voorkom) as die voorkeurvervoermodus van invoerhawens en petroleumraffinaderye af na tenkwerwe by groothandeldepots in Suid-Afrika oorweeg te word (Pienaar 2009:137).

Spoorvervoer ding met tussenhaweskeepvaart mee vir alle soorte goedere. (In die goederevervoermark ding spoor- en lugvervoer nie met mekaar mee nie.)

\section{Sintese van die modale segmente van die goe- derevervoermark}

Grootmaatvragbedrywighede verteenwoordig in die algemeen tans die meeste van die tonnemaat wat deur spoorgoedereoperateurs gekarwei word. Spoorvervoer kan grootmaatbesendings en hoëdigtheidsgoedere teen 'n lae koste oor lang afstande vervoer. Spoorvervoer is dus geskik vir die vervoer van grondstowwe (soos mynbou- en landbouprodukte) en halfvoltooide goedere wat nie maklik beskadig word nie. In die grootmaatvervoermark is deursethoeveelheid en prys belangriker vir die kliënt as reistyd, stiptelike aankomstye en goederesekuriteit (sorgsaamheid). Mits dieertsvoorraad by'n ertsuitvoerhawe byvoorbeeld voldoende is om in die vraag daarna te voldoen, is die aankomstye van individuele treine nie so belangrik nie.

In ander marksegmente, soos standaard- intermodale houerverkeer en losmaatverskeping van halfvoltooide en voltooide goedere, verloor spoorvervoer egter relatiewe markaandeel, want padgoederekarweiers bied in die algemeen gereelde, korter en stipteliker vervoertye. In die geval van die vervoer van intermodale houers in SuidAfrika sedert die 1970's het die absolute volume toegeneem wat per spoor vervoer is, maar spoorvervoer se relatiewe aandeel van hierdie marksegment is aan die krimp (Havenga en Simpson 2016:320). In die geval van losmaatbesendings neem sowel die absolute volume as die relatiewe markaandeel van spoorvervoer af (Havenga et al. 2012:38).

In hierdie ondersoek is bevind dat selfs in gevalle waar spoorvervoer goedkoper as padvervoer is en tussenmodale mededinging fisies moontlik is, goedere eerder per pad as 
TABEL 2: Vergelyking van die vernaamste ekonomiese kenmerke van goederevervoermodusse

\begin{tabular}{|c|c|c|c|c|c|}
\hline Ekonomiese kenmerke & Lug & Pad & Spoor & Pypleiding & Skip (slegs see) \\
\hline Koste & Hoogste & Tweede hoogste & Matig & Tweede laagste & Laagste \\
\hline $\begin{array}{l}\text { Kostestruktuur } \\
\text { (verhouding van vaste } \\
\text { koste tot totale koste) }\end{array}$ & $\begin{array}{l}\text { Gebalanseerd } \\
\text { (soortgelyk aan see) }\end{array}$ & Laagste & Tweede hoogste & Hoogste & $\begin{array}{l}\text { Gebalanseerd } \\
\text { (soortgelyk aan lug) }\end{array}$ \\
\hline Vlootgroottevoordele & $\begin{array}{l}\text { Tweede laagste } \\
\text { (soortgelyk aan see) }\end{array}$ & Tweede hoogste & $\begin{array}{l}\text { Hoogste (verwys na } \\
\text { treinlengte) }\end{array}$ & $\begin{array}{l}\text { Laagste, niebestaande } \\
\text { (verwys na aantal pype) }\end{array}$ & $\begin{array}{l}\text { Tweede laagste } \\
\text { (soortgelyk aan lug) }\end{array}$ \\
\hline Voertuiggroottevoordele & $\begin{array}{l}\text { Tweede hoogste } \\
\text { (soortgelyk aan see) }\end{array}$ & $\begin{array}{l}\text { Matig in absolute } \\
\text { terme, relatief laagste } \\
\text { (soortgelyk aan spoor) }\end{array}$ & $\begin{array}{l}\text { Matig in absolute } \\
\text { terme, relatief laagste } \\
\text { (soortgelyk aan pad) }\end{array}$ & $\begin{array}{l}\text { Hoogste (met verwysing } \\
\text { na pypdeursnee) }\end{array}$ & $\begin{array}{l}\text { Tweede hoogste } \\
\text { (soortgelyk aan lug) }\end{array}$ \\
\hline Ritafstandvoordele & $\begin{array}{l}\text { Tweede hoogste } \\
\text { (soortgelyk aan see) }\end{array}$ & Tweede laagste & Hoogste & $\begin{array}{l}\text { Laagste (bykans } \\
\text { niebestaande) }\end{array}$ & $\begin{array}{l}\text { Tweede hoogste } \\
\text { (soortgelyk aan lug) }\end{array}$ \\
\hline $\begin{array}{l}\text { Oorheersende } \\
\text { binnemodale marktipe }\end{array}$ & Oligopolie & Van oop tot oligopolie & $\begin{array}{l}\text { Natuurlike monopolie } \\
\text { Duopolie as toegang } \\
\text { oop is }\end{array}$ & Natuurlike monopolie & $\begin{array}{l}\text { Oop (huurskepe) tot } \\
\text { oligopolie (lynvaart- } \\
\text { operateurs) }\end{array}$ \\
\hline $\begin{array}{l}\text { Oorheersende tussen- } \\
\text { modale mededinging }\end{array}$ & $\begin{array}{l}\text { Pad: klein besendings } \\
\text { See: oor die oseaan }\end{array}$ & $\begin{array}{l}\text { Spoor: deelvragte en } \\
\text { houers } \\
\text { Lug: klein besendings }\end{array}$ & $\begin{array}{l}\text { Pad: deelvragte en } \\
\text { houers } \\
\text { Kusvaart: alle tipes } \\
\text { goedere }\end{array}$ & $\begin{array}{l}\text { Spoor wanneer } \\
\text { pypleiding naby volle } \\
\text { vermoë bedryf word }\end{array}$ & $\begin{array}{l}\text { Pad en spoor: dienste } \\
\text { tussen plaaslike } \\
\text { hawens. } \\
\text { Lug: oor die oseaan } \\
\text { vir klein hoëwaarde- } \\
\text { besendings }\end{array}$ \\
\hline
\end{tabular}

Bron: Pienaar 2012:46

per spoor vervoer word om dieselfde redes as waarom lugvervoer bo goedkoper transoseaniese skeepsvervoer verkies word (Pienaar 2017:81). Goedere word per pad vervoer eerder as per spoor, en lugvervoer word bo seevervoer tussen dieselfde oorsprong- en bestemmingsplekke verkies wanneer die volgende toetstande geld (ATA 1988:1):

- Wanneer die goedere -

- bederfbaar is;

- aan veroudering binne die bestek van enkele dae onderhewig is (soos koerante);

- op kort kennisgewing benodig word;

- hoë waarde in verhouding tot die massa het; of

- duur is om te verpak, te hanteer of te berg.

- Wanneer die vraag na die goedere -

- onvoorspelbaar is;

- ongereeld voorkom;

- vir kort periodes meer is as die plaaslike aanbod; of

- seisoenaal is.

- Wanneer probleme tydens ritte kan voorkom, soos -

- hoë risiko van diefstal, breekskade of fisiese agteruitgang;

- hoë versekeringsbetalings en/of rentekoste vir lang deurvoertye;

- swaar en/of duur verpakking vir spoor- en skeepsvervoer benodig word; of

- spesiale onderwegsorg benodig word.

Deur bovermelde bevindings rakende die doeltreffendheids- en doelmatigheidsoorwegings in ag te neem soos hulle die vraag na en aanbod van modale goederevervoer raak, was dit moontlik om die modale segmente van die goederevervoermark in nywerheidslande oor die wêreld heen te sintetiseer. Dié sintese word in Tabel 3 aangebied.

\section{Segmentering van die spoorgoede- revervoermark}

In die studie is bevind dat die beste vooruitsig om spoorgoederevervoer op bestendige wyse winsgewend te bedryf, is om op die marksegmente te fokus waarin die nakoming van besondere doelmatigheidsvereistes swaarder weeg as die bereiking van streng doeltreffendheidsvlakke soos dié wat die versenders van halfvoltooide en voltooide hoëwaardegoedere vereis. Daar is verder bevind "(d)at die beste manier om kostedoelmatigheid te bereik, is om die grootste massa en hoeveelheid vrag per tydperk met die mins moontlike totale treinafstand en aantal treinritte te vermag. Hierdie doelwit word nagestreef deur verkeerskonsolidering en die beskikbaarheid van gepaste tegnologie" (Pienaar 2017:82).

Wat betref "gepaste tegnologie" om hulle marksegmente suksesvol te bedien, maak spoorkarweiers deesdae hoofsaaklik gebruik van twee soorte treine, nege soorte doelgeboude trokmodelle en vier soorte spesiaal ontwerpte eindpuntgeriewe wat met gepaste hanteringstoerusting toegerus is. Hierdie kenmerke, tesame met die aard van die goedere wat in elke segment vervoer word, word in Tabel 4 getoon.

Goederetreinsoorte: Goederetreine kan breedweg in twee klasse verdeel word: eenheidstreine en trokvragtreine (Patty 2015:5; Pienaar 2017:83; PwC 2014:5; RailNetEurope [RNE] 2014:33; Symonds Group Ltd 2001:2; TSR 2014:7). 
TABEL 3: Modale segmente van die goederevervoermark

\begin{tabular}{|c|c|c|c|c|c|}
\hline MODUS & $\begin{array}{l}\text { VERNAAMSTE } \\
\text { STERKPUNTE }\end{array}$ & $\begin{array}{l}\text { VERNAAMSTE } \\
\text { BEPERKINGS }\end{array}$ & PRIMÊRE ROL & GOEDERE-EIENSKAPPE & TIPIESE ITEMS \\
\hline Lug & $\begin{array}{l}\text { Kort deurvoertyd } \\
\text { Goederesekuriteit } \\
\text { Betroubaarheid }\end{array}$ & $\begin{array}{l}\text { Ontoeganklikheid } \\
\text { Hoë koste } \\
\text { Klein dravermoë }\end{array}$ & $\begin{array}{l}\text { Dringende diens oor lang } \\
\text { afstande van hoëwaarde- } \\
\text { items en noodvoorraad }\end{array}$ & $\begin{array}{l}\text { Hoë waarde } \\
\text { Voltooid } \\
\text { Bederf en/of verouder gou }\end{array}$ & $\begin{array}{l}\text { Nuusblaaie } \\
\text { Elektroniese items } \\
\text { Pos } \\
\text { Vervangingsonderdele } \\
\text { Medisinale items }\end{array}$ \\
\hline Pad & $\begin{array}{l}\text { Toeganklikheid } \\
\text { Kort deurvoertyd } \\
\text { Buigsaamheid }\end{array}$ & $\begin{array}{l}\text { Beperkte dravermoë } \\
\text { Hoë koste } \\
\text { Kwesbaarheid }\end{array}$ & $\begin{array}{l}\text { Vervoer losvrag- en houer- } \\
\text { besendings in binnelandse } \\
\text { en streeksmarkte }\end{array}$ & $\begin{array}{l}\text { Hoë waarde } \\
\text { Halfvoltooid en voltooid } \\
\text { Verpakbaar/ behouerbaar }\end{array}$ & $\begin{array}{l}\text { Verbruikers- en kruideniers- } \\
\text { ware } \\
\text { Elektroniese en meganiese } \\
\text { items } \\
\text { Huisraad }\end{array}$ \\
\hline Spoor & $\begin{array}{l}\text { Groot dravermoë } \\
\text { Lae koste } \\
\text { Diensomvang }\end{array}$ & $\begin{array}{l}\text { Ontoeganklikheid } \\
\text { Goedereskade } \\
\text { Inkonsekwente diens }\end{array}$ & $\begin{array}{l}\text { Vervoer groot en digte } \\
\text { besendings oor lang } \\
\text { afstande in plaaslike en } \\
\text { streeksmarkte }\end{array}$ & $\begin{array}{l}\text { Droë en nat grondstowwe } \\
\text { Verpakbare/ behouerbare } \\
\text { items } \\
\text { Op-en-afrybaar } \\
\text { Onverpakbare groot items }\end{array}$ & $\begin{array}{l}\text { Ertse } \\
\text { Brandstof, chemikalieë, } \\
\text { aardgas } \\
\text { Graan } \\
\text { Padvoertuie } \\
\text { Meganiese items } \\
\text { Boumateriaal en toerusting } \\
\text { Onverwerkte bosbou- en } \\
\text { landbouprodukte }\end{array}$ \\
\hline Pyp & $\begin{array}{l}\text { Lae koste } \\
\text { Betroubaarheid } \\
\text { Groot dravermoë }\end{array}$ & $\begin{array}{l}\text { Ontoeganklikheid } \\
\text { Beperkte diensomvang } \\
\text { Lang deurvoertyd }\end{array}$ & $\begin{array}{l}\text { Vervoer groot pompbare } \\
\text { besendings in plaaslike en } \\
\text { streeksmarkte }\end{array}$ & $\begin{array}{l}\text { Vloeibaar of vlugtig } \\
\text { Onverpak }\end{array}$ & $\begin{array}{l}\text { Ruolie, brandstof, } \\
\text { chemikalieë, aardgas, } \\
\text { flodder } \\
\text { Water }\end{array}$ \\
\hline See & $\begin{array}{l}\text { Groot dravermoë } \\
\text { Lae koste } \\
\text { Diensomvang }\end{array}$ & $\begin{array}{l}\text { Lang deurvoertyd } \\
\text { Ontoeganklikheid } \\
\text { Lae diensfrekwensie }\end{array}$ & $\begin{array}{l}\text { Vervoer groot besendings } \\
\text { in kusvaart en oor oseane }\end{array}$ & $\begin{array}{l}\text { Droë en nat grondstowwe } \\
\text { Verpakbare/ behouerbare } \\
\text { los items } \\
\text { Op-en-afrybaar }\end{array}$ & $\begin{array}{l}\text { Ertse } \\
\text { Ruolie, brandstof, } \\
\text { chemikalieë, aardgas } \\
\text { Graan } \\
\text { Padvoertuie } \\
\text { Vee } \\
\text { Meganiese items } \\
\text { Huisraad, verbruikersware }\end{array}$ \\
\hline
\end{tabular}

Bron: Eie navorsing

Eenheidstreine bly deurlopend in 'n vaste stel verbind nadat hulle saamgestel is, vervoer dieselfde goederesoort en word tussen dieselfde oorsprong en dieselfde bestemmingseindpunt bedryf sonder om in 'n opstelwerf gesorteer of verdeel te word, maar kan in 'n goederewerf stop gewoonlik in 'n eenheidstreinsylyn - vir inspeksie, om die lokomotiewe te diens of om die bemanning te ruil.

Eenheidstreine is net vir hoëvolumekliënte ekonomies. Aangesien eenheidstreine slegs een soort goedere karwei, is al die trokke van dieselfde soort en is hulle almal dikwels identies, behalwe moontlike variasies in die livrei daarop. Wanneer dit volgens goederesoort geklassifiseer word, is daar drie soorte eenheidstreine. Dit is (1) grootmaatgrondstofeenheidstreine, (2) eenheidstreine vir standaard- intermodale houers en (3) motortrok-eenheidstreine (sogenaamde opry-afry-treine). Die doelmatigheid wat die bedryf van eenheidstreine bied, steun op die verkryging van digtheids- en ritafstandvoordele.

Trokvragtreine bestaan gewoonlik uit individuele trokke wat by afsonderlike plekke met losmaatgoedere (dit wil sê deelvragbesendings) gelaai is en dan na opstelwerwe verskuif word, waar die trokke na gelang van bestemming in treine saamgestel word. Hierna word hulle na 'n opstelwerf naby die bestemming geneem, waar die indivi- duele trokke weer geskei en weer volgens verdere bestemmings in treine saamgestel word.

Konvensionele losmaatspoorgoedere-eindpunte met hul behoefte aan meervoudige sylyne vir die saamstel van treinstelle en die laai en ontlaai van trokke, wat dikwels dae duur en omvangryke spoorkapasiteit in die eindpunt beset, het sedert die ekonomiese deregulering van goederevervoer in nywerheidslande grootliks oorbodig geword en in onbruik verval. 'n Kenmerk van spoorgoederestelsels deesdae is dat die aantal stasies, depots, werwe en haltes verminder word.

Deur die samestelling van trokvragtreine te beperk tot die versending van (a) losmaat-items wat as voltrokvragte deur kliënte aangebied word, (b) standaard- intermodale houers wat vol gepak is met verenigde deelvragbesendings en op houertrokke deur kliënte aangebied word, en (c) grootmaatvloeistof wat in gevulde tenktrokke deur kliënte aangebied word, en deur die ontvangs en aflewering daarvan by minder maar groter stasies te konsentreer, kan spoorvervoeroperateurs enersyds afstandsvoordele behaal deur langer ononderbroke ritte, en andersyds digtheidsvoordele behaal deur die groter benutting van rollende materiaal en die intensiewe gebruik van groot eindpunte. 
Laasgenoemde digtheidsvoordele word inderdaad ten dele deur verskeidenheidsvoordele aangehelp deurdat 'n verskeidenheid losmaatgoedere in voltrokvragte, volgepakte houervragte en gevulde tenktrokke gekonsolideer is en dit by ' $n$ beperkte aantal aangewese losmaateindpunte op- en afgelaai en hanteer word. Hierdie doelmatigheidsvoordeel wat trokvragtreine kan bied, steun dus op 'n hibriditeit van verskeidenheids- en digtheidsvoordele wat die ontbering van die doeltreffendheidsvoordeel wat padvervoer in staat is om te bied, oortref.

Bogenoemde laaipuntaanwysing noodsaak plaaslike insameling en aflewering per pad by hierdie punte. Die ligging van elke punt hang van die verkeersvolume en die beskikbaarheid van plaaslike padvervoer af. Laaipuntaanwysing verkort die duur van 'n hooflyntreinrit en konsolideer die op- en aflaai van vrag. Dit raak egter nie die volume goedere wat op enige gegewe rit per spoor vervoer word nie. In nywerheidslande, en ook in Suid-Afrika, het laaipuntaanwysing gelei tot die uitskakeling van haltes, klein losmaatstasies en private sylyne waar kliënte voorheen losvragbesendings ontvang en afgestuur het.

Die oorsprong van trokvragverkeer kan private sylyne wees. Drie voorbeelde hiervan is (1) groepverkeer, wat besendings is wat vragkonsolideerders uit verskillende versenders se deelvragbesendings saamgestel het en as 'n enkele voltrokvrag of verskeie voltrokvragte aan die spooroperateur aanbied, (2) verkeer wat verband hou met 'n spesifieke aktiwiteit, soos 'n vervaardigingsaanleg of ' $n$ pakhuis wat losmaatgoedere hanteer maar dit slegs as voltrokvragte ontvang en versend omdat 'n kort wagtyd en voorraadhoukoste nie van kritieke belang nie, en (3) aanlegte wat vol houers op houertrokke en onverpakte vloeistof met tenktrokke in trokvragtreine na en van verskeie plekke versend en ontvang omdat dit onvoldoende is om eenheidstreine te vorm.

Troksoorte: Ondersoek het aan die lig gebring dat daar vandag nege soorte spoortrokke is wat internasionaal algemeen gebruik word (Greenbrier 2015; Hinkelman 2018:603-613; TFR 2015:2, 30, 73, 89, 100, 103, 193, 194 en 225). Dit is die (1) toe trok, (2) koeltrok, (3) plat trok, (4) tenktrok, (5) puttrok (6) oop trok, (7) lossertrok, (8) systuten middelafskortingtrok, en (9) motortrok. Hierdie troksoorte word uitvoerig deur Pienaar (2017:83-85) bespreek, en die inhoud daarvan word nie hier herhaal nie. Die aanwending van die trokke, wat wel hier van belang is, word in Tabel 4 getoon.

Eindpuntgeriewe: Hedendaagse goederespooreindpunte kan in vier breë klasse verdeel word: (1) losmaateindpunte; (2) grootmaateindpunte, (3) opry-afry-eindpunte en (4) intermodale eindpunte (Rodrique 2017:195). Hierdie eindpunte word uitvoerig deur Pienaar (2017:85-87) bespreek en die inhoud daarvan word nie hier herhaal nie.

TABEL 4: Hedendaagse troksoorte, tipe treine waarin hulle gebruik word en die tipiese goederesoorte wat hulle dra

\begin{tabular}{|c|c|c|c|}
\hline SOORT TROK & $\begin{array}{l}\text { ILLUSTRASIE VAN SYAANSIG VAN } \\
\text { TROK }\end{array}$ & TIPE TREIN WAARIN GEBRUIK & TIPIESE ITEMS GEDRA \\
\hline Toe trok & $\int_{2}$ & Trokvragtrein & $\begin{array}{l}\text { Weersensitiewe items, meesal in } \\
\text { kiste, kratte, bale, sakke, bondels en } \\
\text { op palette. }\end{array}$ \\
\hline Koeltrok & & Trokvragtrein & $\begin{array}{l}\text { Bederfbare items soos groente, } \\
\text { vrugte, sap, rooi- en witvleis, vis/ } \\
\text { seekos, suiwelprodukte. }\end{array}$ \\
\hline Plat trok & & Eenheidstrein en soms trokvragtrein & $\begin{array}{l}\text { Behouerde goedere en onverdeelbare } \\
\text { groot items. }\end{array}$ \\
\hline Tenktrok & & Eenheidstrein en soms trokvragtrein & $\begin{array}{l}\text { Vloeistowwe, gas, poeiers en fyn } \\
\text { verkorrelde stowwe. }\end{array}$ \\
\hline Puttrok & & Eenheidstrein en soms trokvragtrein & $\begin{array}{l}\text { Hoëkubushouers en oopdakhouers vir } \\
\text { buitengewoon hoë items. }\end{array}$ \\
\hline $\begin{array}{l}\text { Oop trok } \\
\text { 1. Gewoon } \\
\text { 2. Kantelbaar of omkeerbaar }\end{array}$ & & $\begin{array}{l}\text { 1. Trokvragtrein } \\
\text { 2. Eenheidstrein }\end{array}$ & $\begin{array}{l}\text { 1. Onverwerkte nieweersensitiewe } \\
\text { bosbou- en landbouprodukte; } \\
\text { metaalvoorwerpe; en los ruwe items. } \\
\text { 2. Mynbouprodukte. }\end{array}$ \\
\hline $\begin{array}{l}\text { Lossertrok } \\
\text { 1. Oop } \\
\text { 2. Bedek }\end{array}$ & & Eenheidstrein & $\begin{array}{l}\text { 1. Mynbouprodukte. } \\
\text { 2. Vogvatbare items soos graan, } \\
\text { suiker en kunsmis. }\end{array}$ \\
\hline Systut- en middelafskortingtrokke & & Trokvragtrein & $\begin{array}{l}\text { Lang onverdeelbare items soos } \\
\text { stompe, pale, maste, stawe, relings, } \\
\text { pype, lere en panele. }\end{array}$ \\
\hline Motortrok & the & Eenheidstrein & $\begin{array}{l}\text { Ligte padvoertuie: motors, bakkies, } \\
\text { stasiewaens, paneelwaens en } \\
\text { minibusse. }\end{array}$ \\
\hline
\end{tabular}


TABEL 5: Tegnologiese kenmerke van die onderskeie spoorgoederemarksegmente en die aard van die goedere wat in elke segment vervoer word

\begin{tabular}{|c|c|c|c|c|}
\hline MARKSEGMENT & $\begin{array}{l}\text { TIPE TREIN AANGE- } \\
\text { WEND }\end{array}$ & TIPE TROKKE GEBRUIK & $\begin{array}{l}\text { EINDPUNTE GEBRUIK EN HULLE } \\
\text { LIGGINGS }\end{array}$ & $\begin{array}{l}\text { GOEDERESOORTE IN SEGMENT } \\
\text { BEDIEN }\end{array}$ \\
\hline Losmaat & Trokvragtrein & $\begin{array}{l}\text { Toe trok } \\
\text { Koeltrok } \\
\text { Plattrok } \\
\text { Tenktrok } \\
\text { Oop trok } \\
\text { Systuttrok }\end{array}$ & $\begin{array}{l}\text { Losmaateindpunte: } \\
\text { Klein goederewerf - teenaan 'n passasier- } \\
\text { stasie } \\
\text { Middelslag- en groot goederewerf - } \\
\text { met sylyn verbind met geassosieerde } \\
\text { passasierstasie } \\
\text { Groot en onafhanklike goederewerf op } \\
\text { private sylynkompleks }\end{array}$ & $\begin{array}{l}\text { Items wat nie gepas is vir } \\
\text { standaardbehouering of } \\
\text { grootmaatvervoer nie. (kan wel } \\
\text { items in enkele houers en vloeistof } \\
\text { in enkele tenktrokke wees wat as } \\
\text { losmaatgoedere voorkom) }\end{array}$ \\
\hline $\begin{array}{l}\text { Grootmaat: mynbou- } \\
\text { produkte }\end{array}$ & Eenheidstrein & $\begin{array}{l}\text { Oop lossertrok } \\
\text { Oop trok (kantelbaar en } \\
\text { omkeerbaar) }\end{array}$ & $\begin{array}{l}\text { Ertseindpunte: } \\
\text { Op private sylyne by myne, kragstasies en } \\
\text { verwerkingsaanlegte } \\
\text { Sylyne by invoerhawens en uitvoerhawens }\end{array}$ & $\begin{array}{l}\text { Ertse - meesal yster, mangaan, } \\
\text { koper, graniet, chroom en steenkool }\end{array}$ \\
\hline $\begin{array}{l}\text { Grootmaat: vloei- } \\
\text { stowwe }\end{array}$ & $\begin{array}{l}\text { Eenheidstrein } \\
\text { (sien losmaatsegment } \\
\text { vir enkele tenktrokke) }\end{array}$ & Tenktrok & $\begin{array}{l}\text { Tenktrokeindpunte: } \\
\text { Op private sylyne by raffinaderye en } \\
\text { tenkwerwe (pypleidings tussen invoer-/ } \\
\text { uitvoerhawens en naaste tenkwerf of } \\
\text { raffinadery) }\end{array}$ & $\begin{array}{l}\text { Ruolie } \\
\text { Brandstof - meesal petrol, diesel, } \\
\text { paraffien en vliegtuigbrandstof } \\
\text { Chemiese produkte - meesal sure } \\
\text { Aardgas }\end{array}$ \\
\hline Grootmaat: graan & Eenheidstrein & Bedekte lossertrok & $\begin{array}{l}\text { Graaneindpunte: } \\
\text { By graansuiers op private en operateur- } \\
\text { sylyne in produksiegebiede en by invoer- } \\
\text { en uitvoerhawens }\end{array}$ & $\begin{array}{l}\text { Grootmaatgraan - meesal mielies } \\
\text { en koring }\end{array}$ \\
\hline $\begin{array}{l}\text { Oprybare en afrybare } \\
\text { items }\end{array}$ & Eenheidstrein & Motortrok & $\begin{array}{l}\text { Opry-en-afry-eindpunte: } \\
\text { Op private en operateursylyne by } \\
\text { voertuigfabrieke, streeksdistribusiepunte, } \\
\text { en invoer- en uitvoerhawens }\end{array}$ & $\begin{array}{l}\text { Ligte padvoertuie: } \\
\text { Motors, minibusse, paneelwaens, } \\
\text { bakkies en stasiewaens }\end{array}$ \\
\hline $\begin{array}{l}\text { Standaard- } \\
\text { intermodale houers }\end{array}$ & $\begin{array}{l}\text { Eenheidstrein } \\
\text { (sien losmaatsegment } \\
\text { vir enkele houers) }\end{array}$ & $\begin{array}{l}\text { Plattrok } \\
\text { Puttrok }\end{array}$ & $\begin{array}{l}\text { Intermodale eindpunte: } \\
\text { Op private en operateursylyne by invoer- } \\
\text { en uitvoerhawens (aan kaai en naby kaai) } \\
\text { Operateursylyne by aansluitstasies } \\
\text { Private alleenstaande sylynkomplekse by } \\
\text { lokuspunte in nywerheidsgebiede }\end{array}$ & $\begin{array}{l}\text { Enige halfvoltooide en voltooide } \\
\text { items wat in standaard- } \\
\text { intermodale houers pas. }\end{array}$ \\
\hline
\end{tabular}

Bron: Eie navorsing

Ter wille van die konteks hier ter sprake, word die vernaamste bedryfskenmerke van die onderskeie eindpuntgeriewe in Tabel 5 getoon.

Met die inligting wat tydens die buitelandse feitesendings van spoorvervoeraanbieders en deur waarnemings verkry is, was dit moontlik om, soos in Tabel 5 getoon, die spoorgoederevervoermark in segmente te verdeel wat potensieel op bestendige wyse winsgewend in Suid-Afrika bedien kan word. Hierdie segmente van die spoorgoederevervoermark is soos volg: (1) losmaatgoederevervoer, (2) grootmaatvervoer van (a) mynbouprodukte, (b) vloeistowwe en (c) graan; (3) op-en-afrydienste, en (4) standaardintermodale houervervoer.

\section{Gevolgtrekkings}

Goederevervoerdienste word deur die volgende vyf vervoermodusse aangebied: lug, pad-, spoor-, pypleidingen skeepsvervoer.

Die primêre rol van elke modus is soos volg: lugvervoer bied dringende dienste oor lang afstande van hoëwaardeitems en noodvoorraad; padvervoer verskaf losvrag- en houerkarweiding in binnelandse en streeksmarkte; spoor- vervoer behartig die vervoer van groot en digte besendings oor lang afstande in plaaslike en streeksmarkte; pypleidings vervoer groot pompbare besendings in plaaslike en streeksmarkte; en skeepsvervoer per see bied die vervoer van groot besendings van enige soort goedere in kusvaart en oor oseane aan.

Spoorgoederevervoer bied dienste in die volgende marksegmente: (1) losmaatgoedere; (2) grootmaatvervoer van (a) mynbouprodukte, (b) vloeistowwe en (c) graan; (3) open-afrydienste; en (4) standaard- intermodale houers.

Wat losmaatvervoer betref, het die gunstige dienskenmerke van padvervoer in vergelyking met dié van spoorvoervoer versenders minder afhanklik van die losmaatverskeping van hoëwaarde- halfvoltooide en voltooide goedere per spoor gemaak. In hierdie marksegment is veilige, betroubare en regstreekse deur-tot-deur-dienste teen konsekwente reistye met stiptelike aankomstye en 'n groter oplaai- en afleweringsreëlmaat, asook goedereversenders se vooruitsig om tydens die vervoerproses groter beheer oor besendings te hê, hoedanighede wat die status van padvervoer as voorkeurmodus vir die vervoer van losmaatbesendings onderskraag. Die groter waarde wat 
doeltreffende padvragkarweiers deur beter diensgehalte in vergelyking met dié van spoorvervoer bied, oortref in die algemeen die hoër koste van padvervoer vergeleke met dié van spoorvervoer in hierdie marksegment.

In die ondersoek is bevind dat spoorkarweiers, onderworpe aan een of meer van die volgende drie voorwaardes, wel losmaatvervoer op bestendige wyse winsgewend kan aanbied: (1) Die ontvangers van besendings moet nie begaan wees oor kort deur-tot-deur-deurvoertye en knapbetydse aflewerings nie. (2) Dit moet moontlik wees om van laaipuntaanwysing gebruik te maak deur slegs sekere punte aan te wys waar besendings op- en afgelaai word. (3) Kliënte moet bereid wees om slegs voltrokvragte te ontvang en te versend - gewoonlik omdat 'n kort wagtyd en voorraadhoukoste nie van kritieke belang nie.

Wat die bedryf van eenheidstreine betref, behaal spoorvervoer aansienlike digtheids- en ritafstandvoordele met hoë benutting omdat die eenheidskoste afneem wanneer die uitsetvermoë toeneem - en selfs in hoër mate in die geval van lang treine, 'n dubbelspoorstelsel (of 'n enkelspoor met voldoende uitwykspore vir die verbygaan van aankomende treine en van stadiger treine in dieselfde rigting), en gespesialiseerde trokke, eindpuntgeriewe en hanteringstoerusting wat vinnige dog veilige ritte tussen eindpunte en kort treinomdraaitye by eindpunte moontlik maak. Om dié rede maak spoorkarweiers toenemend van eenheidstreinbedrywighede gebruik.

Die deelmarksegmente in nywerheidslande wat die winsgewendste met eenheidstreine bedien word, is (1) grootmaat-grondstofeenheidstreine, (2) eenheidstreine vir standaard- intermodale houers, en (3) motortrok-eenheidstreine.

Wat grootmaat-grondstofeenheidstreine betref, karwei hierdie eenheidstreine hoëdigtheidgrondstowwe, soos mynbou- en landboukommoditeite en onverpakte vloeistowwe, in grootmaatbesendings oor lang afstande teen lae koste. In die mark vir grootmaat-langafstandvervoer van grondstowwe is deurset en prys belangriker vir die kliënt as die tydsduur van die reis en stiptelike afleweringstye. Solank opgepotte grondstof by die bestemming voldoende is, is die aankomstye van individuele treine nie belangrik nie.

Ofskoon eenheidstreine wat grootmaatgraan vervoer, in die algemeen ook winsgewend bedryf word, is benuttingsvlakke van hierdie deelmark kwesbaar weens die seisoenale aard daarvan en weens die voorkoms van eenrigtingleëbeenverkeer omdat graan ná oessurplusse op groot skaal uitgevoer word en ná oestekorte op groot skaal ingevoer word.

Wat eenheidstreine vir standaard- intermodale houers betref, word hierdie soort eenheidstreine in Suid-Afrika om veral vier redes winsgewend bedryf. Eerstens word 'n hoë mate van digtheidsvoordele behaal deurdat 50 houers of meer per trein vervoer word en die treine 'n kort omdraaityd by eindpunte het. Tweedens word hierdie treine op roetes van aansienlik langer as 500 kilometer bedryf (tussen die hawens van Durban, Port Elizabeth en Kaapstad en die binnelandse provinsie Gauteng). Derdens is die stiptelike knapbetydse aflewering van die loonvrag van hierdie soort eenheidstreine nie altyd van oorheersende belang nie, omdat (a) die houers bloot betyds moet wees om gelaai te word op 'n houerskip, wat feitlik altyd nog nie gereed vir die laaiproses is nie, en (b) die houers vanaf ' $n$ hawe na eindpunte in Gauteng dikwels vir enkele groot kliënte bestem is wat nie onmiddellik die volle besending benodig nie. Vierdens is daar ' $n$ groot waarskynlikheid van goeie heen-en-weer-benutting aangesien daar voortdurend vol houers vir versending by beide roete-eindpunte gelewer word.

Wat motortrok-eenheidstreine betref, word hulle in SuidAfrika om veral drie redes winsgewend bedryf. Eerstens word 'n hoë mate van digtheidsvoordele behaal deurdat 100 ligte voertuie of meer op volgelaaide treine vervoer word en die treine 'n kort omdraaityd by opry-en-afryeindpunte het. Tweedens word hierdie treine op roetes van aansienlik langer as 500 kilometer bedryf (tussen in- en uitvoerhawens, van voertuigvervaardigingsaanlegte en verspreidingsentra in Durban, Oos-Londen, Port Elizabeth en Kaapstad na en van voertuigvervaardigingsaanlegte en verspreidingsentra in Gauteng). Derdens is daar ' $n$ groot waarskynlikheid van goeie heen-en-weer-benutting, aangesien daar voortdurend ligte voertuie vir versending by opry-en-afry-eindpunte by ritoorspronge en -bestemmings gelewer word.

\section{Verwysings}

Africon. 2008. Study on the macro-economic impact of fuel costs in transport. Contract report produced for the National Department of Transport, Pretoria.

Amos P. 2007. Vertical Separation of Railways. World Bank, Washington DC.

Andersen SJ. 1995. Modal choice strategies for freight distribution in Southern Africa, PhD dissertation. Stellenbosch University, Stellenbosch.

Anderson HJR, Basson MB. 1997. 'n Studie na die diens, kwaliteit en risiko's van die vervoer van gebotteleerde drank per pad. Gesamentlike MEcon/MCommtesis. Universiteit Stellenbosch, Stellenbosch.

Air Transport Association of America (ATA), 1988. Air Cargo from A to Z. Air Transport Association of America, Washington DC.

Bureau for Economic Research, Stellenbosch University (BER), 2003. The feasibility of a fuel tax levy in the Western Cape. Stellenbosch University, Stellenbosch.

Bonsor NC. 1984. Transportation Economics: Theory and Canadian Policy. Butterworths, Toronto.

Committee of Transport Officials (СОTO). 2017. Socio-economic analysis of road projects: Technical methods for highways (TMH) 20, Committee Draft CD1. COTO, Pretoria.

Cowie J. 2010. The Economics of Transport: A Theoretical and Applied Perspective. Routledge, London.

Coyle JJ, Langley CJ, Novack RA, Gibson BJ. 2017. Supply Chain Management: A Logistics Perspective, 10th edition. Cengage Learning, Boston.

Department of Logistics, Stellenbosch University, 1998. Report to Petronet on the development of a defensible pricing mechanism. Department of Logistics, Stellenbosch University, Stellenbosch.

Di Pietrantonio L, Pelkmans J. 2004. The economics of EU railway reform. European Economic Policy Briefing 8. College of Europe, Bruges. 
European Conference of Ministers of Transport (ECMT). 2004. European integration of rail freight transport. Round Table 125. ECMT, Paris.

Greenbrier Companies (The). 2015. European rail manufacturing. Available: http:// www.gbrx.com (accessed on 18 August 2015).

Havenga JH, De Bod A, Simpson Z. 2012. South Africa's domestic intermodal imperative. Research in Transportation Business \& Management 5, 38-47.

Havenga JH, Pienaar WJ. 2012. The creation and application of a national freight flow model for South Africa. Journal of the South African Institution of Civil Engineering 54(1), 2-13.

Havenga JH, Simpson ZP. 2016. Freight logistic's contribution to sustainability: Systemic measurement facilitates behavioural change. Transportation Research Part D 2016, 320-331.

Hinkelman EG. 2018. Dictionary of International Trade, 12th edition. World Trade Press, Petaluma, California.

Liberatore MJ, Miller T. 1995. A decision support approach for transport and mode selection. Journal of Business Logistics 16(2), 85-15.

Papacostas CS, Prevedouros PD. 2001. Transportat ion Engineering and Planning, 3rd edition. Englewood Cliff s, Prentice-Hall, New Jersey.

Patty BW. 2015. Handbook of Operations Research Applications at Railroads. Springer, New York.

Pienaar WJ. 2007. 'n Voorgestelde reguleringsraamwerk vir pad- en spoorvragvervoer in Suid-Afrika. Suid-Afrikaanse Tydskrif of Natuurwetenskap en Tegnologie 26(4), 265-278.

Pienaar WJ. 2009. Ekonomiese aspekte van pypleidingvervoer: 'n Suid-Afrikaanse perspektief. Suid-Afrikaanse Tydskrif of Natuurwetenskap en Tegnologie 28(2) 119-139.

Pienaar WJ. 2012. Overview of salient economic features of the modes of freight transport for use in the formulation of national transport policy in South Africa. Risk governance and control: financial markets and institutions 2(2), 33-47.

Pienaar WJ. 2017. Bedryfs- en tegnologiese vereistes vir die winsgewende lewering van spoorgoederevervoer. Suid-Afrikaanse Tydskrif vir Natuurwetenskap en Tegnologie 36(1), 79 - 89.
Pittman R. 2005. Structural separation to create competition? The case of freight railways. Review of network economics 4(3), 181-196.

Pretorius J. 1997. The effect of conditions in the transport sector on the competitiveness of South African industries in foreign markets, MComm thesis. Stellenbosch University, Stellenbosch.

PricewaterhouseCoopers Advisory SpA (PwC). 2014. Study on single wagonload traffic in Europe: Objectives, results and recommendations. Report prepared for Community of European Railway and Infrastructure Companies (CER), Brussels.

Rabinow RA. 2004. The liquid pipeline industry in the United States: Where it's been, where it's going. Report prepared for the Association of Oil Pipe Lines. Available: http://www.aopl.org/about/pipelines.html (accessed on 4 July 2015).

Rodrique J-P. 2017. The Geography of Transport Systems, 4th edition. Routledge, London.

Stock JR, Lambert DM. 2001. Strategic Logistics Management, 4th edition. McGrawHill, New York.

Symonds Group Ltd. 2001. A study of single wagonload rail traffic. DirectorateGeneral for Energy \& Transport, European Commission, Brussels.

Transnet Freight Rail (TFR), 2015. Wagon Book. TFR, Johannesburg.

Transnet School of Rail (TSR), 2014. Functional Yard Operations, Reference FYO_08: Yard Layout. TFR, Johannesburg.

Trench CJ, Miesner TO. 2006. The role of energy pipelines and research in the United States: Sustaining the viability and productivity of a national asset. Pipeline Research Council International. Available:http://www.aopl.org/ about/pipelines.html (Accessed on 4 July 2015).

University of Birmingham and Network Rail, 2011. Railway Lexicon, Reference Rai Lexicon Mark 24. University of Birmingham, Birmingham.

Van de Venter H. 1989. Sinjaalbeginsels van die Suid-Afrikaanse Vervoerdienste. SAVD, Johannesburg. 